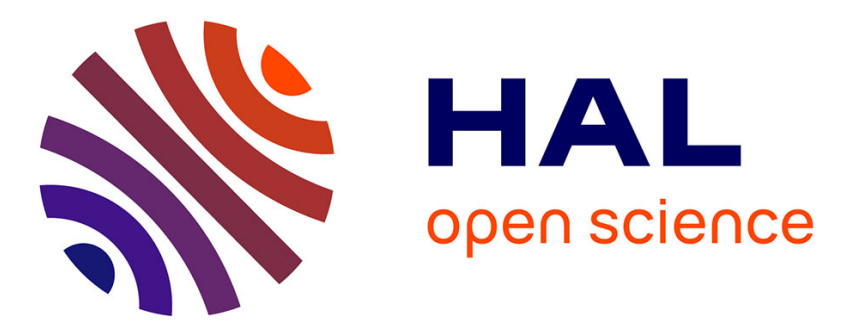

\title{
Port regionalisation from a relational perspective: the rise of Venlo as dutch international logistics hub
}

Nicolas Raimbault, Wouter Jacobs, Frank van Dongen

\section{To cite this version:}

Nicolas Raimbault, Wouter Jacobs, Frank van Dongen. Port regionalisation from a relational perspective: the rise of Venlo as dutch international logistics hub. Tijdschrift Voor Economische en Sociale Geografie, 2016, 107 (1), pp 16-32. 10.1111/tesg.12134 . hal-01740678

\section{HAL Id: hal-01740678 \\ https://hal.science/hal-01740678}

Submitted on 2 Jan 2022

HAL is a multi-disciplinary open access archive for the deposit and dissemination of scientific research documents, whether they are published or not. The documents may come from teaching and research institutions in France or abroad, or from public or private research centers.
L'archive ouverte pluridisciplinaire HAL, est destinée au dépôt et à la diffusion de documents scientifiques de niveau recherche, publiés ou non, émanant des établissements d'enseignement et de recherche français ou étrangers, des laboratoires publics ou privés. 


\title{
Port regionalisation from a relational perspective.
}

\section{The rise of Venlo as Dutch international logistics hub}

\author{
Nicolas RAImBaULT ${ }^{1}$, Wouter JACoBS ${ }^{2}$ and Frank VAN DonGEN ${ }^{3}$
}

Raimbault, N., Jacobs, W. and van Dongen, F. (2016), Port Regionalisation from a Relational Perspective. Tijdschr Econ Soc Geogr, 107: 16-32. https://doi.org/10.1111/tesg.12134

\begin{abstract}
:
The rise of global supply chain systems and geographical dispersion of related inland logistics centres has led to a new phase in the evolution of port systems, referred to as port regionalisation (Notteboom and Rodrigue, 2005). While this process largely results from the decisions of shippers and logistics providers, the scope of public policy can also shape it. This includes the strategic capacity of stakeholders to couple not only locally available assets with the needs of global flows, but also to provide meaning through the constitution of symbols, frames and discourses. We propose the application of a relational perspective to port regionalisation, which allows us to analyse how various actors engage strategically in actor-networks and coalitions across scales to stimulate growth based on logistics. This is accomplished by presenting the rise of Venlo in the Netherlands as an inland logistics hub within the corridor of the port of Rotterdam.
\end{abstract}

Keywords: Port Regionalisation, Logistics, Netherlands, Relational Approach, Greenport Venlo.

\section{I) Introduction}

The rise of global supply chain systems and geographical dispersion of related inland logistics centres has led to a new phase in the evolution of port systems and port-city interface. Notteboom and Rodrigue (2005) have referred to this phase as port regionalisation, which is characterised by seaports becoming integral parts of extensive intermodal hinterland networks, corridors and inland intermodal terminals. According

\footnotetext{
1 Paris - Est University; IFSTTAR - SPLOTT; 14-20 Boulevard Newton, Cité Descartes, Champs sur Marne; F77447 Marne la Vallée Cedex 2; France; nicolas.raimbault@ifsttar.fr

2 Institute of Transport and Maritime Management Antwerp (ITMMA) - University of Antwerp;

ITMMA House; Kipdorp 59; B-2000 Antwerp; Belgium; and Department of Social and Economic Geography, Ghent University, Ghent, Belgium ; Wouter.jacobs@ua.ac.be

3 PBL- Netherlands Environmental Assessment Agency; The Hague; The Netherlands; frank.vandongen@pbl.nl.
} 
to the seminal paper of Notteboom and Rodrigue, the process of port regionalisation is largely the result of the location and routing decisions of shippers and logistics service providers; however, the scope of public policy can also shape the spatial contours of the process, although it remains case-specific and dependent on various types of local and national contingencies and institutional contexts (cf. Wilmsmeier et al., 2011; Monios and Wilmsmeier, 2012).

The spatial and functional-economic outcomes of the port regionalisation process have indeed become a reality in many countries (Wilmsmeier et al., 2011) and under different institutional contexts. Many inland locations have been identified by transport geographers as hubs (e.g., Liège, Tilburg, Venlo, Duisburg in the Rhine-Scheldt Delta) in multiport gateway-hinterland transport networks (Notteboom, 2009). Nonetheless, according to Monios and Wilmsmeier $(2012)^{4}$, the main theoretical issue raised by the port regionalisation concept is the direction of its development and identification of the main drivers. They compared two directions of port regionalisation: landside-driven (referred to as inside-out) or seaside-driven (outside-in). These two directions correspond to the interests of different types of actors driving the regionalisation process: public port authorities and private terminal operators on the one hand and rail operators and public organisations on the other hand.

However, such a dichotomy of development trajectories and outcomes is problematic because it precludes the possibility that both directions can be at play simultaneously. Certain actors, such as firms (e.g., private terminal operator) or higher levels of government beyond the local scale, can have stakes at multiple locations that include the seaside and landside of the logistics chain. Many of the problems in the current theories, as we will argue throughout the paper, have to do with how agency is considered in relation to institutional structure (cf. Hesse, 2013 for similar approach).

Therefore, port regionalisation as it is currently studied applies actor-network thinking, but is logistics-centric and follows a reductionist ontology or instrumental logic with regards to regional development. Networks are primarily perceived as transport flows and logistics chains, but they do not consider, for instance, how agency can lobby governments and align with institutional actors to secure interests or pursue development agendas through networking. The issue of governance mostly refers to coordination problems within the logistics chain (e.g., Van der Horst and De Langen, 2008) and largely ignores how governance takes place in terms of regional-economic and spatial (strategic or land use) planning. As such, contemporary studies neglect the roles that other actors beyond the logistics scenery play in facilitating or constraining the port regionalisation process. These actors must not be in favour of logistics-based

\footnotetext{
${ }^{4}$ Their perspective, inspired by actor-network thinking, echoes a similar approach as in planning theory developed by Boelens (2009).
} 
development at all, and developing a location into an inland logistics hub is just one among many alternative routes for regional development to proceed. Indeed, it is striking that the economic impacts of port regionalisation on inland locations have hardly been studied until now (see: Van den Heuvel, et al., 2013).

However, the various degrees of power that actors might hold and the ways that such power is exercised in the port regionalisation process is an issue that is mostly overlooked in the literature (see: Jacobs and Notteboom, 2011). Not every actor holds the same degree of power or can mobilise the same type of (institutional) resources as support. In this case, much depends on the spatial scale at which actors operate and how they gain leverage across scales (from the global to the local) and within relational networks (cf. Cox, 1998; Jacobs and Lagendijk, 2014). Finally, spatio-temporality is also a neglected issue in the literature on port regionalisation. While port regionalisation suggests a process, one that has been ongoing for at least 20 years, contemporary case study analyses primarily focus on the outcomes. These case studies neglect to a large extent historical or evolutionary accounts of how inland logistic hubs developed and became institutionally endorsed.

To overcome these problems, we propose the application of a relational perspective to port regionalisation (see also Jacobs and Notteboom, 2011; Jacobs and Lagendijk, 2014). This allows us to focus on how regional development results from relational constructs and social formations that are constituted through ongoing actorspecific practices and processes across territorial scales within institutionalised structures. As such, we will be able to overcome the problem of the institutional context perceived as a constraining factor in the understanding of nationally different outcomes in the port regionalisation process. Rather, a relational perspective understands institutions as one of many assets to be mobilised by agency in the pursuit of their goals (cf. Jacobs, 2007). Central to our approach is the concept of 'strategic coupling' (cf. Coe et al. 2004) and how we can apply it to analyse the role of agency in aligning various forms of locally available assets (inside-out) with 'global' network demands (outside-in) in a dynamic context.

This is accomplished by presenting the rise of Venlo in the Netherlands as an inland logistics hub within the corridors of the ports of Rotterdam and Antwerp. The case of Venlo is compelling because it has been labelled in previous transport geographical studies as a "satellite terminal for Rotterdam" (Rodrigue et al. 2010: 525) and an "extended gate" to the ECT Delta Terminal located in the port of Rotterdam (Rodrigue and Notteboom 2009: 177). These very real observations led Monios and Wilmsmeier (2012) to conclude that the development of Venlo has followed an outsidein logic-driven process led by a private port terminal operator, which is in contrast to their more general conclusion that port regionalisation in Europe and the US has followed an inside-out pattern. Therefore, the case of Venlo stands out; however, in light of the problematic issues addressed above, it also deserves closer empirical inquiry. If we accept the proposition that port regionalisation is both an outcome of inside-out and 
outside-in drivers and driving agents, how can we understand its rise through relational processes across scales and within institutional contexts?

Therefore, the aim of this research is to add to the debate on port regionalisation, both theoretically and empirically. Theoretically, we add a relational perspective that allows port regionalisation to be viewed as a mutual constitutive process among actors, networks and structures. Empirically, we revisit Venlo as an internationally outstanding case that has barely been empirically investigated until now beyond the logic of the ECT business model. Through the case study of Venlo, we would like to induce further theoretical thoughts on port regionalisation; in particular, we would like to discuss how to move beyond its functionalist account of regional development and overcome the problem of institutional contexts. Therefore, we also hope to direct the discussion beyond that of 'hard-core' transport geographers and induce insights from other scholars interested in the classical port-city interface, such as planners, urban geographers and urban historians.

The outline of this paper is as follows. In the first section, we discuss the process of port regionalisation as an extension of James Bird's classical Anyport model (1963), which was identified by Notteboom and Rodrigue (2005). In the second section, we then make our case for a relational approach to port regionalisation and put forward the concept of strategic coupling as a method of understanding how structure and agency interact in regional development processes. In the third section, we revisit the case of Venlo and demonstrate the status of Venlo as a Dutch inland logistics hub within the Rhine-Scheldt Delta (outcome). The fourth section explains the rise of Venlo as a logistics hub through the lens of strategic coupling (process). We emphasise that the development of Venlo is best understood as an interplay between inside-out and outside-in and global and local forces. The fifth section presents the conclusions.

\section{II) Port Regionalisation from a Relational Perspective}

From Anyport to Port Regionalisation- The spatial and functional evolution of port systems, in particular the dynamic and fraught relationship between ports and cities, are well-conceptualised phenomena among geographers and planners (Bird, 1963; 1973; Hayuth, 1982; Hoyle, 1989; Norcliff et al. 1996). The most influential work regarding this phenomena is that of James Bird (1963) and his concept of the Anyport, wherein three phases (settlement, expansion and specialisation) are distinguished in the evolution of port cities. Because of the rise of spatially extensive supply chain systems and development of inland container hubs along transport corridors, Notteboom and Rodrigue (2005) added a new phase to Bird's Anyport model: port regionalisation.

The essence of this phase is that warehouse, distribution and logistics activity moves further inland and away from the initial port city. The move is driven by various structural pull and push factors. The most important push factor is the lack of affordable land close to the port in combination with congestion on the main highways and container terminals. Most of the commodities shipped by container are consumer goods 
or production components in demand in the port's hinterland and to a far lesser degree in the direct urban economy. In other words, once arriving at the port, there is no need for the container to stay much longer in the port's vicinity. Therefore, the most important pull factor to move logistics activity inland is the proximity to the consumer market and to benefit from a strategic location along transport corridors where land (and labour) is abundant and accessibility is superior. The most strategic location is where several transport modes converge so that the location can be served by several seaports in the wider region (cf. Van den Heuvel et al., 2013), also referred to as a multiport gateway region (Notteboom, 2009).

Therefore, Notteboom and Rodrigue added a much needed phase in Bird's outdated model that focuses on the continuation of port and related logistics activity and is contrary to others who have primarily focused on the struggles of the redevelopment processes at the initial waterfront in the city (Norcliff et al.1996; Wiegmans and Louw, 2011; Hein, 2011). Not only did port regionalisation extend the Anyport model into the container age, it also addressed the issues of scale and agency. The port-city interface was regionalised with externalities and values operating beyond the local scale and classical 20th century urban perimeter (cf. Hall and Hesse, 2013; Hesse, 2013). Moreover, port regionalisation involves the simultaneous functional-economic and spatial integration of ports, inland logistics zones, suburban and urban economies and hinterlands. It views ports and inland hubs as nodes in international freight flows, transportation networks and logistics chains.

Monios and Wilmsmeier (2012) raised the issue of the direction and drivers of port regionalisation. The original paper of Notteboom and Rodrigue (2005) insisted on a market-driven nature of port regionalisation that developed "from logistics decisions and subsequent actions of shippers and third-party logistics providers" (2005: 306). Furthermore, in the context of the "terminalisation of supply chains," private port based terminal operators were becoming active in inland supply chain management and deeply involved in port regionalisation strategies (Rodrigue and Notteboom, 2009). Likewise, local governments in the hinterland were involved because they might facilitate or prevent such logistics developments in their jurisdiction through all types of politically mediated land use plans. For example, Valburg near Nijmegen in the Netherlands was initially planned to be the inland logistics hub because of its directplanned connection with the to-be-constructed Betuweline freight rail line and strong support by the Dutch logistics industry for its development, most notably the support of the Port of Rotterdam Authority and Rotterdam-based private terminal operator ECT. Nonetheless, local politicians in Nijmegen ultimately blocked its development because they doubted the forecasted benefits for the local economy.

The latter example raises an important point: port regionalisation can be successfully opposed. Developing a location into an inland logistics hub or 'extended gateway' is only one among many economic alternatives. Different actors have different interests and hold different degrees of 'power,' both within actor-networks (e.g., a value 
chain) and institutionally (e.g., regulations). Power should be viewed here not as 'power over,' such as in the command of resources, but as 'power to,' which is to employ such resources strategically in multi-actor games. Institutions are in this context not only as a set of constraining rules but also as enablers and 'territorial assets' when they are actively employed by the appropriate agencies. Therefore, when analysing port regionalisation as an outcome, not only must the direction (outside-in or inside-out) be determined and drivers (private or public actors) be identified, but the methods by which these factors are strategically aligned through the process of agency must also be determined. For that, we want to address a relational approach.

Strategic coupling as a relational approach to port regionalisation- The relational approach gained scholarly ground within economic geography and planning within the previous decade (Storper, 1997; Dicken et al. 2001; Bathelt and Glückler, 2004; Yeung, 2005; Sunley, 2008). The essence of the relational approach is that we cannot understand spatial processes without considering specific relationships that exist between places, between different actors in places and between actors and their institutional contexts. Spatial dynamics are therefore relationally constituted through interactions and place-specific (traded and non-traded) interdependencies among actors (Storper, 1997).

The relational approach "allows us to avoid the two polarised frameworks in contemporary economic geography - actor networks and institutional structures" (Yeung, 2005: 38), and thus to "identify the complex relational geometry comprising local and non-local actors, tangible and intangible assets, formal and informal institutional structures, and their interactive power relations." The relational approach in economic geography is particularly profound in work on global production networks (GPN) (cf. Dicken et al. 2001; Coe et al. 2004; Coe et al. 2008; Yeung, 2009) that focus on 'globalising regions.' In particular, the GPN approach is concerned with how regions become inserted in various global flows (information, capital and goods) and align with various functions of transnational corporations. The insertion and alignment is not only a process imposed by global forces on 'the region' because a scope remains for action by locally dependent interests to strategically engage with other centres and networks of 'social power' to gain leverage, mobilise agents and resources, or build strategic coalitions (cf. Cox, 1998; Jacobs and Lagendijk, 2014). A key concept within the GPN approach on regional development is strategic coupling.

In its original meaning, strategic coupling involves the deliberate employment of regional assets to accommodate the demands and needs of 'global' players, plugging the region into global networks of exchange and flows of goods (cf. Coe et al. 2004). Yeung (2009, p. 332) defines strategic coupling "as a mutually dependent and constitutive process involving shared interests and cooperation between two or more groups of actors who otherwise might not act in tandem for a common strategic objective." This definition echoes earlier US-based work on the politics of local economic development, such as the growth machine (Logan and Molotch, 1987) and urban regimes (Stone, 1989). However, 
such a 'localist' or 'regionalist' view on economic development should be avoided. Rather, strategic coupling should be viewed as a relational process across various scales in which actors assign a particular meaning and value to certain locally available assets (cf. Yeung, 2009).

Strategic coupling is a relational capacity that accumulates from continuous interactions among agents and institutions and materialises in various networks, governance arrangements, discourses and the actual employment of resources and production factors (Jacobs and Lagendijk, 2014):

"One should therefore understand strategic coupling as networked power relations in the mobilization of resources (including the constitution of symbols of 'centrality,' 'competitiveness' or 'sustainability') that support and improve a territory's position in global flows."

(Jacobs and Lagendijk, 2014, p. 59).

The mobilisation of resources (material and institutional) and employment of certain local or regional assets may therefore involve certain relationally constituted symbols, or what are also known in planning and public policy debates as frames and discourses. These frames and discourses can help to align actors around common objectives and opportunities or to consider collective action problems (Hajer, 1995; Van den Brink, 2009). According to Rein and Schön (1986, p. 4), framing stands for "a way of selecting, organizing, interpreting and making sense of a complex reality so as to provide guideposts for knowing, analyzing, persuading and acting." According to the planning theorist Faludi (1996), important to the formulation of frames is their naming and institutional endorsement or sponsorship in various governance arenas and policy circles. Naming allows certain elements or issues to be focused on or demarcated while neglecting others. It allows for the structuration of cognition and common understanding across actors on what is at stake so that a shared and meaningful perspective can facilitate appropriate collective action. Spatially visualised images, conceptual metaphors and narratives all form powerful communicative tools in the framing process.

Therefore, a relational approach to port regionalisation is focused on how actors engage strategically in actor-networks across scales and how they employ various available assets (material, institutional and discursive) to stimulate growth based on logistics at certain inland locations. We will apply these thoughts to the case study of Venlo, the Netherlands, which is an inland logistics hub strategically located between the major seaports of Rotterdam and Antwerp and the Rhine-Ruhr area in Germany. We will reconstruct how Venlo-based stakeholders manage to secure their interests through three phases of "strategic coupling": first by the formation of a locally based coalition, second by strategic engagement with the national spatial planning-framework through 
discursive practices and third by the implementation of new governing tools. The empirical research is based on desktop research of policy documentation ${ }^{5}$, data analysis of regional economic development ${ }^{6}$ and 10 interviews with key-representatives in Venlo and Rotterdam conducted by the lead author in 2012 and 2013.

\section{III) Venlo as inland logistics centre}

Venlo is strategically located in the east of the Netherlands along the border with Germany in the north of the province of Limburg; it is approximately $150 \mathrm{~km}$ from both the ports of Rotterdam and Antwerp and only $50 \mathrm{~km}$ from Europe's largest inland port Duisburg. Venlo offers multimodal options because it is directly connected by major highways with both Rotterdam (A15-A73) and Antwerp (A-67/E-34) that extend into Germany. Through the Maas River (which is directly linked with the Rhine through a canal), Venlo is also accessible by barge and connected with Europe's main inland waterway system. By rail, Venlo is connected with the port of Rotterdam through the socalled 'Brabant-route'. The rail and barge (container) terminals in Venlo are operated by Rotterdam-based ECT through a joint venture with a locally based firm, Seacon Logistics. ECT developed their first inland (rail) terminal in 1982 and a second terminal in 1992, which was followed by a barge terminal in 2010. In 2010, ECT handled approximately 200,000 TEU in Venlo.

\footnotetext{
${ }^{5}$ Available upon request

${ }^{6}$ For the data analysis, the LISA register was used. For all business establishments with paid jobs in the Netherlands, this database contains information regarding the location, amount of jobs, and industrial activity (NACE-codes) on a yearly basis.
} 
Figure 1: The location of the Greenport Venlo in the Rhine-Scheldt Delta (own compilation)

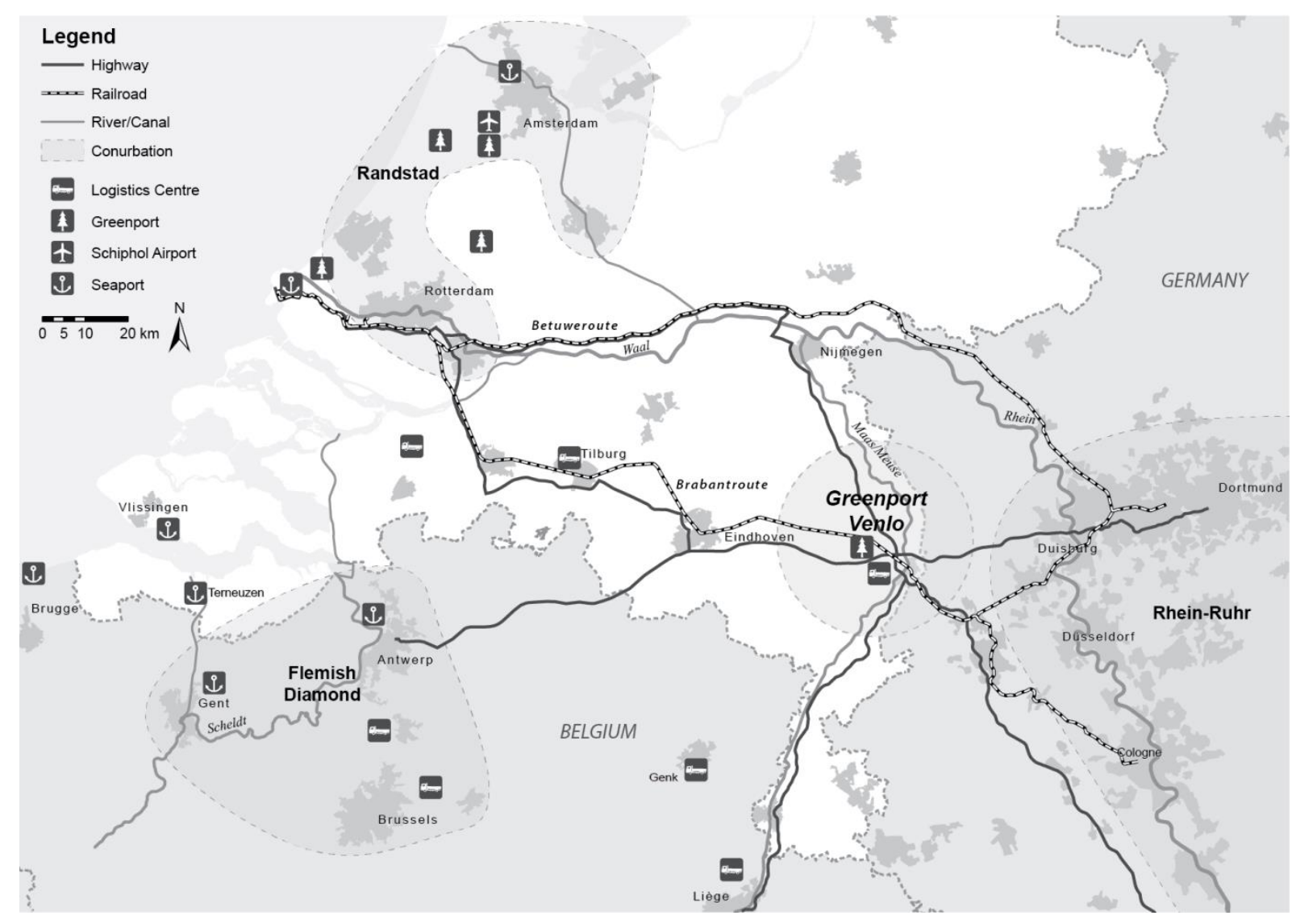

Because of its strategic geographical location, Venlo has benefitted from the local demand for logistics services. First, the region has historically been an important agrofood production centre that was mainly dedicated to exports. Second, the presence of a small but innovative business electronics cluster surrounding home-grown Océ (now part of Canon) led to a local market in need of forwarding and logistics solutions. Venlo is the birthplace of a number of transport firms, such as Frans Maas (now part of DSV), Janssen Distribution, Gaston Schul, Emons Group and Seacon Logistics. These transport firms took full advantage of the location of Venlo by specialising in bonded warehouses and customs clearance services of goods coming from the ports of Rotterdam and Antwerp and destined for Germany. Especially after the Schengen Agreement of 1985 in the advent of the Common Market (1992), certain large shippers using the port of Rotterdam selected Venlo as the location for their European Distribution Centres. At that time, Rotterdam-based terminal operating company ECT selected Venlo to develop inland rail and barge terminals, allowing ECT to offer extended gateway services to its marine terminals located in Rotterdam. In its wake, major international logistics players, such as DHL, UPS, DB Schenker, Géodis, Ziegler and DSV, began to set up operations in Venlo as well.

Since 2005, Venlo has been elected six times as the logistics hotspot of the Netherlands by the professional magazine "Logistiek." It confirms both the economic 
specialisation of Venlo in logistics activities (tab.1) and the importance of Venlo in the national logistics structure (tab.3). Our analysis of employment ${ }^{7}$ over time (1996-2011) through a location quotient index shows the increased specialisation of Venlo in logistics activities $^{8}$. Taking into account only transport firms, the Venlo region increased from number 4 in 1996 to number 1 in 2011 (tab. 2). In terms of wholesaling activities, it increased from number 25 to number 15. According to our definition of logistics activities, Venlo is ranked number 3, whereas it was only the $13^{\text {th }}$ region in 1996 (tab. 1). Thus, logistics activities now represent $30 \%$ of the GDP of the Venlo region (cf. Viaport Venlo) compared with the national average of 7.5\% GDP.

Table 1: Importance of logistics activities in the regional economy in terms of location quotient (Source: LISA, 2011).

\begin{tabular}{|l|l|l|l|l|l|l|}
\hline & \multicolumn{7}{|c|}{ Logistics } \\
\hline Urban Region & $\mathbf{1 9 9 6}$ & Rank & $\mathbf{2 0 0 3}$ & Rank & $\mathbf{2 0 1 1}$ & Rank \\
\hline Zuidwest-Gelderland & 1.59 & 1 & 1.66 & 1 & 1,63 & 1 \\
\hline Oost-Zuid-Holland & 1.34 & 3 & 1.37 & 3 & 1.46 & 2 \\
\hline Noord-Limburg (Venlo region) & 1.02 & 13 & 1.30 & 6 & 1.40 & 3 \\
\hline Zuidoost-Zuid-Holland & 1.28 & 6 & 1.33 & 4 & 1.40 & 4 \\
\hline Groot-Rijnmond (Rotterdam region) & 1.49 & 2 & 1.33 & 5 & 1.35 & 5 \\
\hline Delft en Westland & 1.29 & 5 & 1,39 & 2 & 1.28 & 6 \\
\hline West-Noord-Brabant & 1.15 & 8 & 1,19 & 8 & 1.27 & 7 \\
\hline Midden-Noord-Brabant & 1.12 & 9 & 1,19 & 9 & 1.26 & 8 \\
\hline Noordoost-Noord-Brabant & 1.01 & 15 & 1,19 & 7 & 1.23 & 9 \\
\hline Flevoland & 1.04 & 11 & 0,99 & 16 & 1.09 & 10 \\
\hline
\end{tabular}

\footnotetext{
${ }^{7}$ We conducted our data analysis at the regional scale (NUTS III in EU standardised data collection) because logistics poles generally fall outside of municipal borders, which is the case with Venlo. Furthermore, Noord-Limburg is now at the political scale of Venlo Regio, which is in charge of land and economic development policies (see section 4).

${ }^{8}$ Similar to Van der Heuvel et al. (2013), we defined logistics employment as the total of wholesaling employment and transport employment.
} 
Table 2: Importance of transport activities in the regional economy in terms of location quotient (Source: LISA, 2011)

\begin{tabular}{|l|l|l|l|l|l|l|}
\hline & \multicolumn{7}{|c|}{ Transport } \\
\hline Urban Region & $\mathbf{1 9 9 6}$ & Rank & $\mathbf{2 0 0 3}$ & Rank & $\mathbf{2 0 1 1}$ & Rank \\
\hline Zuidwest-Gelderland & 1.71 & 3 & 1.85 & 1 & 1.96 & 2 \\
\hline Oost-Zuid-Holland & 0.84 & 23 & 0.88 & 20 & 0.99 & 14 \\
\hline Noord-Limburg (Venlo region) & 1.43 & 4 & 1.77 & 2 & 2.02 & 1 \\
\hline Zuidoost-Zuid-Holland & 1.35 & 5 & 1.32 & 6 & 1.30 & 7 \\
\hline Groot-Rijnmond (Rotterdam region) & 2.00 & 1 & 1.76 & 3 & 1.86 & 3 \\
\hline Delft en Westland & 0.96 & 15 & 0.92 & 18 & 0.96 & 18 \\
\hline West-Noord-Brabant & 1.24 & 6 & 1.23 & 8 & 1.45 & 5 \\
\hline Midden-Noord-Brabant & 1.20 & 7 & 1.26 & 7 & 1.48 & 4 \\
\hline Noordoost-Noord-Brabant & 0.96 & 16 & 1.10 & 13 & 0.97 & 16 \\
\hline Flevoland & 0.57 & 38 & 0.64 & 34 & 0.77 & 27 \\
\hline
\end{tabular}

With a stock of 1.3 million $\mathrm{m}^{2}$, the Venlo region is one of the most important concentrations of warehousing space in the Netherlands after the regions of Rotterdam, Amsterdam and West-Noord-Brabant (tab. 3).

Table 3: Warehouse stock and occupancy rates in Dutch logistics centres (source: CBRE, 2011)

\begin{tabular}{|l|l|l|}
\hline Urban Region & Warehouses stock $\mathbf{~ ( m}^{\mathbf{2}} \mathbf{)}$ & Rank \\
\hline West-Noord-Brabant & $2,625,000$ & 1 \\
\hline Groot-Amsterdam & $1,950,000$ & 2 \\
\hline Groot-Rijnmond (Rotterdam region) & $1,573,000$ & 3 \\
\hline Noord-Limburg (Venlo region) & $1,385,000$ & 4 \\
\hline Midden-Noord-Brabant & $1,275,00$ & 5 \\
\hline Noordoost-Noord-Brabant & 965,000 & 6 \\
\hline Zuidoost-Noord-Brabant & 860,000 & 7 \\
\hline Oost-Zuid-Holland & 855,000 & 8 \\
\hline Utrecht region & 595,000 & 9 \\
\hline Arnhem/Nijmegen region & 516,000 & 10 \\
\hline
\end{tabular}

The rise of Venlo as an inland logistics hub is not only explained by geographical factors or pure market forces alone but also by different local public and private actors 
in support of logistics-based regional economic development. Thus, our aim is to study the interplay between these different drivers. As such, we use the concept of strategic coupling as introduced above.

\section{IV) The Greenport Venlo: strategic coupling at work}

Strategic coupling is the way in which actors align themselves relationally to insert Venlo into global (logistics) networks and can be analysed through three phases. The first phase started in the 1980s with a locally based coalition of private and public actors working in tandem to promote Venlo as a logistics centre. These local actions were primarily aimed at securing land for logistics development, setting up appropriate governance mechanisms and forging ties with stakeholders related to the Mainport Rotterdam. The second phase started in the late 1990s and is characterised by discursive practices aimed at securing national government recognition through the Greenport-policy frame. In the third phase from the 2000s onwards, we see a further 'territorialisation' of the Greenport policy and continuation of the logistics-based growth. Only recently have truly global logistics players, especially real estate developers, become an essential developmental force.

Strategic Coupling I: local coalition formation, land-based development and capacity building- Venlo was far from a 'globalising region' in the 1980s in terms of the GPN-approach (Coe et al., 2004); however, logistics-based development began to dominate the local agenda after the advent of the European Common Market. Coalitions between the local business sector and municipality were forged at that time and focused on accommodating logistics interests through three main policies: land-based development, connection to the Port of Rotterdam and local capacity building:

"How can we facilitate this [logistics development]? By having enough space with terminals and through a dedicated team led by a program manager."

(Interview: Municipality of Venlo)

"Venlo clearly said we want logistics. And that makes business easier."

(Interview: Prologis)

The main asset of Venlo at that time was the availability of municipal land. Logistics development requires huge plots of land, and the municipality of Venlo supported logistics-based growth by assigning land use and formal planning mechanisms. In the Netherlands, local governments traditionally have strong positions on the land market, and municipalities are involved in land assembly and development before such land is sold to the private sector (cf. Needham, 1997; Buitelaar et al. 2007). Thus, facilitating logistics growth by means of land policy is an opportunity for the municipality to earn revenue to finance other municipal policies. This can be understood as the physical or material dimension of the strategic coupling process. The business zones dedicated to logistics are the Venlo Trade Port East, West and North and total 
1,400 ha (fig.3) developed by the municipality on former farm land along the main infrastructure corridors northwest of the historic city of Venlo.

The second aspect of this first phase of strategic coupling was the connection with the port of Rotterdam. Since the mid-1980s, the port of Rotterdam had regained its national momentum for growth and successfully launched its Mainport policy in conjunction with a more fundamental neo-liberal driven paradigm shift in the Dutch political economy (Jacobs, 2007). Links with the port of Rotterdam date back to that time because the Rotterdam-based ECT $^{9}$ was granted the management contract of the rail-terminal in 1982 (and of the barge terminal in 2010) in the Venlo inland port. The municipality of Venlo took a pro-active role in forging these connections:

"It is because we were invited by the municipality. The municipality was the owner at that time, and the mayor was very interested in attracting the development of Rotterdam and its containers and being connected."

(Interview: ECT)

The relationship with the port of Rotterdam is symbolic. Until now, they remain of utmost importance for Venlo-based stakeholders. Coordination between the Port of Rotterdam Authority and Venlo still happens on a regular basis.

"We do have a lot of contacts with people in Venlo of course. Venlo is very important for us. (...)We really help parties (...) to develop logistics: participation in projects; all kinds of institutional groups we participate in, speaking at conferences. There you present your hinterland strategy and mention the importance of this hinterland."

(Interview: Port of Rotterdam Authority)

This is, however, a two-way relationship. Venlo provides the port of Rotterdam with space and 'extended gates' in the hinterland (i.e., port regionalisation), whereas Rotterdam secures Venlo international leverage because it allows Venlo to strategically connect with global players and the flows they control:

"The Port of Rotterdam can sell Venlo to global investors; they have more contacts internationally than we have. Sometimes we say: we are 'Rotterdam East!'”

(Interview: Municipality of Venlo)

Furthermore, the local logistics-based coalition was also built on local governance arrangements. The local logistics firms are highly organised to voice their concerns visà-vis the municipality. 'Venlo Freight Village Association,' 'Ondernemend Venlo Tradeport' and 'Ondernemend Limburg' are the more important firms. To lobby the local government, they mainly use the local arena formed by the local promotion and innovation program for logistics called "Viaport Venlo." The firms define the agenda of

\footnotetext{
${ }^{9}$ In the 1980s, ECT's stakeholders included the Dutch state-owned national railway company NS.
} 
this program, but it is financed by the municipality. This way, they are associated in every public project concerning freight and logistics. Therefore, Viaport Venlo strengthens the organising capacity of the logistics interests and to a certain degree institutionalises the private participation in local economic governance:

"In the governance structure [of both the Viaport Venlo and the region of Venlo], the private sector is leading. So (...) [the local-based entrepreneurs are] more important than the Alderman. (...) It is very unique in the Netherlands. [In this program] we pay, but we don't decide."

(Interview: Municipality of Venlo)

Consequently, the municipality of Venlo is lobbying itself to the national government and province of Limburg for its logistics development:

"Logistics is one of their [Venlo's] target sectors, so they do a lot of lobbying at The Hague [the national government] and the province of Limburg. It is good. They know logistics is very important so they really make an effort to improve it."

\section{(Interview: Venlo Freight Village Association)}

Furthermore, logistics became a formalised concern within the municipal administrative apparatus that was carefully linked with the private sector through personal networks. Some civil servants of the economic development department in Venlo are dedicated solely to logistics, and key politicians and civil servants work or have worked in the logistics sector. Thus, the local logistics-based coalition materialised as a network of key persons - entrepreneurs, civil servants and politicians - sharing common paradigms on regional development. For instance, the current Alderman for economic affairs previously worked for logistics firms and was the head of a powerful national logistics lobby:

"Our Alderman was the director of the national association "Holland International Distribution Council." He knows what to do and who to talk when we are in the United States and in Asia to attract new logistics business to Venlo."

(Interview: Municipality of Venlo)

At the same time, Venlo has slowly constituted itself as a port authority. It collects port dues and now prefers to lease land in the Venlo Trade Port rather than sell it (as it did with the barge container terminal). In this way, the Venlo Municipality is more and more financially dependent on logistics growth and not just land development.

Eventually, the main output of the local logistics-based coalition will perhaps be symbolic. Venlo appears to investors as the natural place for logistics:

"For Venlo, logistics is their foundation, their existence because they are at the crossroads of river and roads. It is absolutely a history of organic things. You cannot create it. (...) It is in Venlo's genes." 
In substance, this first strategic coupling corresponds to a local public private coalition whose aim is to strengthen the competitiveness of the local firms to take advantage of the port regionalisation of Rotterdam. Thus, the inland global - regional market mechanisms and local policies could be joint drivers of an "inside-out" port regionalisation process. Moreover, the presence of ECT in the coalition shows that "inside-out" and "outside-in" strategies are not necessarily totally disconnected processes.

Strategic Coupling II: Engagement with national policy discourses- The policy frame of 'Greenport' has its origins in the Dutch horticultural sector of the early 2000s. The frame was launched by key stakeholders in preparation of a newly commissioned national spatial planning vision, the Nota Ruimte (2004). Of particular significance in the policy frame is the use of '-port'; in contrast to 'green,' it is not something one immediately associates with horticulture. The use of '-port' was deliberately used to invoke a particular meaning and to assign a certain level of importance: framing is naming (Faludi, 1996). By framing the interests of the Dutch horticultural sector in terms of a 'port,' specific links were made with the existing policy frame of 'Mainport' used since the mid-1980s in official policy circuits and documentation to promote the growth and competiveness of the port of Rotterdam and Schiphol Airport as the main carriers of the Dutch economy. The use of 'port' in the frame also allowed for the explicit link with the horticultural sector's orientation on export and consequential importance of supply chains, logistics and physical accessibility of the Dutch horticultural clusters.

Next to naming, the policy frame required institutional endorsement or sponsorship. The strategic and economic importance of the Greenport(s) became formally acknowledged by the national government in their 'Nota Ruimte' of 2004:

"Netherlands is the market leader in agribusiness sectors. They form the basis of a knowledge-intensive agribusiness complex that is concentrated in a few locations of national importance: the 'Greenports.' The future development of the Dutch Greenports is closely related to the development of the Mainports [Port of Rotterdam and Schiphol Airport] in terms of innovation, transport, accessibility and spatial accommodation within the urbanised areas of the country. To strengthen the international competitiveness of the Netherlands, the Dutch government supports the development of Greenports." (original in Dutch, italics added by authors)

The Dutch government granted six areas the status of 'Greenport': Venlo, Westland, Boskoop, Duin and Bollenstreek, Aalsmeer (in 2005) and Noord-Holland Noord (in 2011). Representatives from both the public and private sector from these Greenports first convened officially in 2005 and resulted in an official implementation agenda 'Greenport(s) Nederland. Manifest voor Uitvoering' in 2006. Because it was named a Greenport, the economic importance of Venlo was recognised for the first time in national policy circles and development strategies. 
"The meaning of Greenport is excellence. Venlo is indeed good in these sectors, but the problem was that nobody knew about it. (...) Then, we said 'wait a minute, we are a Greenport!' That was the first time we said 'we host excellence'. And we obtained the Floriade. It was the first time the national government recognised our regional excellence. (...) It worked!"

(Interview: Municipality of Venlo)

The political momentum and institutional endorsement at a national scale offered by the Greenport policy enabled local logistics stakeholders in Venlo to strategically couple their concerns with national development programs. In other words, the new context brought by the Greenport frame represented a window of opportunity for Venlo to engage more efficiently in logistical 'actor-networks' across scales to stimulate growth. The Venlo coalition succeeded in adapting the Greenport frame to its logistics project, i.e., they "territorialised" (Faure, 2010) it, meaning that Venlo defined its own localised economic problems around logistics competiveness leads to a territorial differentiation of the Greenport policy compared to the national definition and the redefinition of sectors and actors involved in this public policy beyond the influential lobby of the Dutch horticultural sector:

"When we say Greenport Venlo, everybody thinks only about agribusiness or agro and foods, perhaps agro logistics. We must be clear: Greenport Venlo is more than that. Yes, it is agribusiness, it is agro foods and it is also industry. However, it is always logistics. Logistics in general."

(Interview: Municipality of Venlo)

The local territorialisation of the Greenport as a "cluster of agro food industries and horticulture and logistics activities important to competitiveness" 10 has been explicitly recognised by the national spatial planning a posteriori. Finally, the policy frame entails new legitimacy for logistics development. The Floriade organised in 2012 offered " $a$ landmark because we are a Greenport" and displayed the local discourse around the, linking agribusiness, logistics and regional development.

"This year, we will have a lot of events thanks to the Floriade: the Netherlands distribution association will be in Venlo, the congress of the association of Dutch inland ports - all of them are at the Floriade. For us, the Floriade is more than agribusiness, it is really business to business, next to attracting visitors."

(Interview: Municipality of Venlo)

However, although the Greenport frame secured a national endorsement for growth and linked logistics with export-based agribusiness, its meaning for logistics companies remained limited:

\footnotetext{
10 Ontwerp Structuurvisie Infrastructuur en Ruimte, 2011 : p71
} 
"When we profile ourselves to logistics companies, we refer to Tradeport, which works better for logistics: the Tradeport in the umbrella of the Greenport."

(Interview: DCGV)

"Which label is the best for us: Greenport or tradeport? None of them. Just Venlo. That is known. Our customers don't care about labels, they just think about logistics zones."

(Interview: Prologis)

Therefore, from a regional development perspective, being included in the Greenport discourse offers the opportunity to obtain more attention from the national government in terms of formal recognition and financing:

"The central government has no money anymore. However, we caught the national government's attention. This is important. When they are investing in the rail network, they know we are an important region, so they will think about us. The chances that will we obtain money for development are bigger."

(Interview: Municipality of Venlo)

Eventually, this discursive phase of strategic coupling secured national policy recognition and support. This way, national policies can constitute resources for local strategies without directly shaping port regionalisation. Moreover, the discursive practices with regards to the Greenport are accompanied with new governance arrangements that allows for further strategic engagement with global logistics.

Strategic Coupling III: New enabling governance tools- The governance arrangements created by the Greenport framework allowed for local stakeholders to remove the municipal political constraints on economic and land development policies and govern logistics development through new tools. In a way, this arrangement resembled the more general shift towards what is referred to by critical scholars as 'urban privatism' and the 'post-democratic city' (cf. Macleod, 2011). Among the policy transformations, new ways of governing the built environment are emerging. This transformation has become highly strategic to capture the global logistics players (Hesse, 2004, Raimbault, 2013a, 2013b). Two of the leading global real estate firms are Prologis and Goodman, and they are especially important in aligning the region with global networks:

"Nowadays, Prologis and Goodman attract companies too. They are in the global network. In 2011, Goodman started developing a new DC for DSV's Unilever supply chain. So you see because they invest, DSV acquired this 5-year contract with Unilever. So I think that Goodman and Prologis are very important for our region."

(Interview: Municipality of Venlo)

Above all, the new governance structure, called Greenport Venlo, is politically and operationally in charge of the Greenport project (cf. figure 2). Greenport Venlo is a foundation under private law; therefore, it is less constrained than a municipal administrative department. The municipalities of the region, the province of Limburg and the local employers' association ("enterprising Limburg") sit on its board. Greenport 
Venlo implements most of the local economic development policies that were once the responsibility of the municipality:

"Greenport Holland, that structure is very public. However, Greenport Venlo, that is a cooperation with firms. And if you look at logistics, you see we are very successful in this kind of cooperation."

(Interview: Municipality of Venlo)

"In the municipality, you have not only to go to the alderman but also to the municipal council. That does not work. In a private organization, it is safe."

(Interview: Municipality of Venlo)

It also leads to a new scale of implementation of local economic development policies. This used to be the only responsibility of the municipality of Venlo; but now it is conducted at the scale of the wider region:

"Before Greenport and Floriade, we never worked together. All the municipalities were looking at each other in concurrence. Since then, they have worked well together, in cooperation. It is very unique. Not a lot of regions work together in this way."

(Interview: Municipality of Venlo)

Figure 2: Greenport Venlo governance arrangements (own compilation)

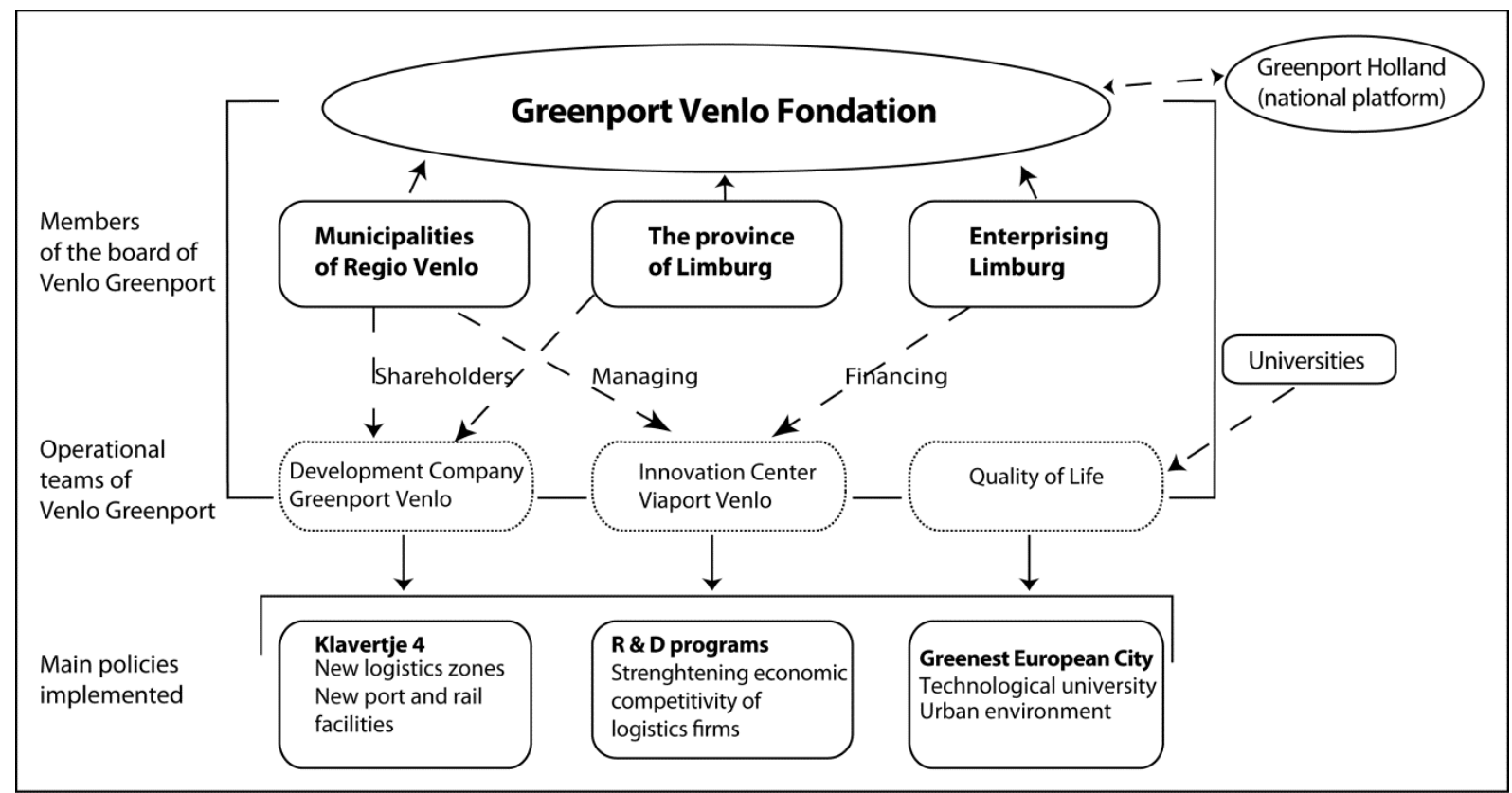

This institution is more adapted to the new logistics context, especially in terms of real estate and infrastructure. The infrastructure development program consists of a huge development project called Klavertje 4 and representing 5,400 ha, among which there are 2000 ha of logistics zones and one million square meters of warehouses in addition to the 1.5 million already used. There is a new rail terminal project in the area (cf. figure 3) and to implement the project, a new public land development company has been funded: Development Company Greenport Venlo (DCGV). The province of Limburg 
and all of the municipalities of the region are its shareholders (cf. figure 2). It is run as a private company according to private law and represents a strong rupture with the past because the lucrative land development policies were traditionally handled by municipalities. Having a huge land development project and dedicated company to run the project are unique situations among the Dutch Greenports. The total investments in the project are projected to be $€ 743$ million and it should generate $€ 961$ million in revenues for the DCGV, which is equivalent to a net income of $€ 218$ billion. Therefore, each year, DCGV will re-invest $70 \mathrm{M} €$.

Figure 3: Logistics parks, agribusiness and infrastructure in the Venlo region (own compilation)

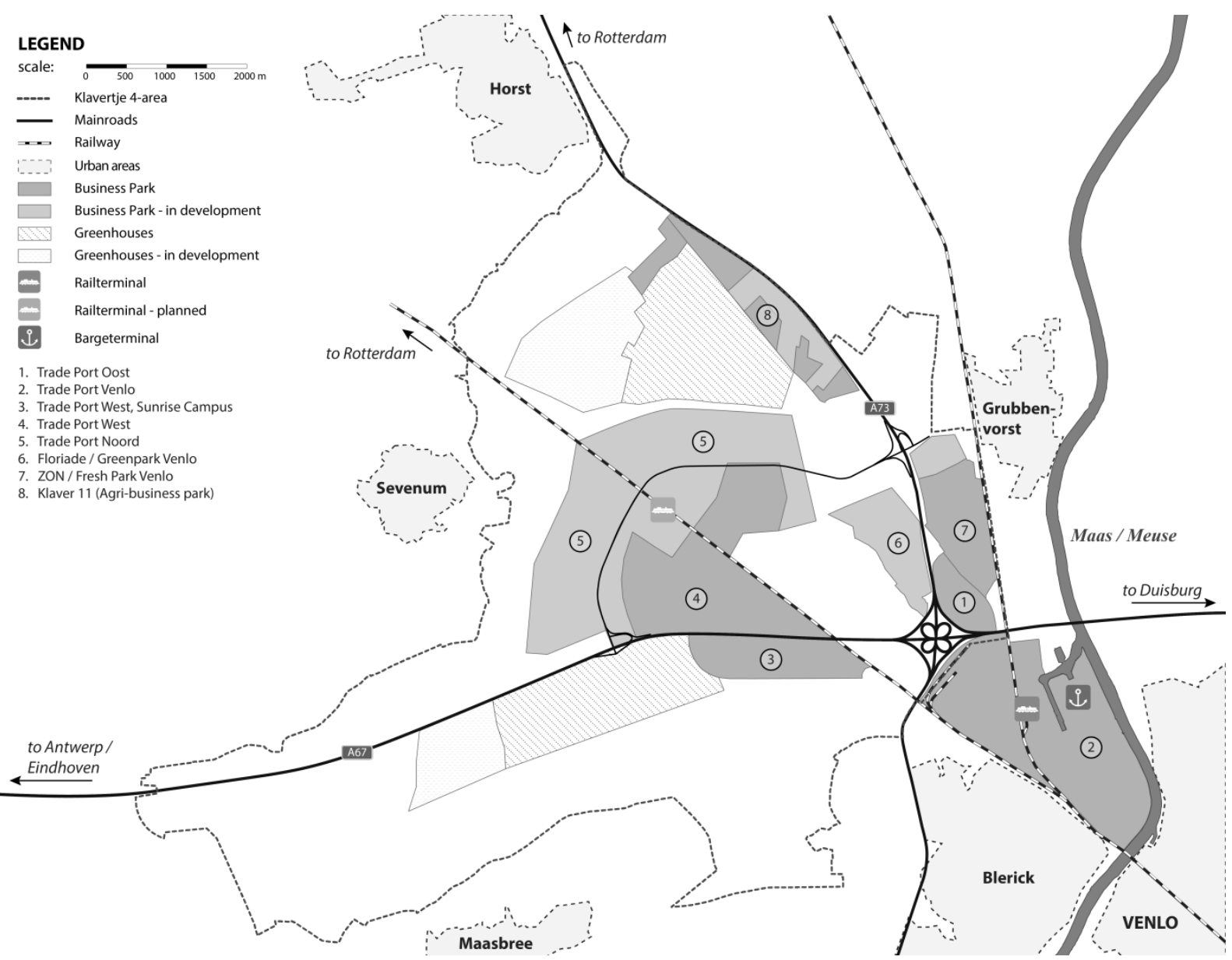

This allows the DCGV to provide (financial) incentives to firms. This new organisation is more reactive to the demands of global logistics real estate developers and investors such as Prologis, Goodman or WDP.

"Because the Greenport company is also real estate people, they understand business. Municipality, it is difficult. It is not real estate. (...) So it is easier to communicate."

(Interview: Prologis) 
According to Prologis, working with a development company instead of a municipal board could permit this firm to implement its strategy of developing logistics parks, which necessitates privatising the land development process:

"What is different compared to central Europe and also France, where we have parks with five or six buildings, is that in the Netherlands, we have municipalities that are only selling land per plot. So we can only buy land for one warehouse. And the road in front is still owned by the municipality. So we have to do case by case, plot by plot, and because of that, you get a warehouse here, a warehouse there. (...) However, in Venlo (...), we are now negotiating with Greenport to let us develop the land as a main developer. (...) There is one of the plots [of Venlo Trade Park North] that is big enough. (...) It is the only plot I think almost in all the Netherlands."

(Interview: Prologis)

In fact, Goodman has just developed a park that includes three huge distribution centres in the Venlo Tradeport North, which is the first logistics zone of the Klavertje 4. Thus, a new coalition has been forged through the DCGV that involves the global real estate developers and investors. This new coalition is able to attract bigger logistics providers, such as DHL, UPS and Géodis, and logistics real estate developers and investors are also selling Venlo to global markets:

"One of the points I always say to the municipality is: see us as an ambassador of your region. Because we are financially interested in your region, your problem is my problem. (...) And I want to develop. So I am one of the ambassadors of Venlo."

(Interview: Prologis)

The coalition around the DCGV is not a substitute for the first coalition of the regional firms forged through the Viaport Venlo. This latter coalition is still at work under the umbrella of the Greenport Venlo foundation within the "Innovation Centre," which is the institution dedicated to innovation and research programs (cf figure 2). The two coalitions are partly disconnected because the real estate investors and global logistics providers do not participate in the promotion and innovation programs.

The territorialisation of the Greenport frame in Venlo, therefore, has led to a new mode of production of logistics spaces that aligns material, institutional and symbolic assets with growth based on logistics. Conversely, it embeds the interests of global logistics players through the built environment. In terms of strategic coupling, this last phase is characterised by a real estate-based coalition that intends to attract new distribution centres of the largest international logistics services providers and shippers. In particular, it is changing the way local economic development is governed locally so that it is more attuned to the business model of international real estate developers. 


\section{V) Conclusions}

The conceptual understanding of port systems and the port-city interface has moved beyond Bird's classical 'Anyport' model. However, whereas planners and urban geographers focused on the antagonistic processes involved in waterfront redevelopment, transport geographers introduced a regionalisation phase to the Anyport model. This phase is characterised by containerised, integrated and spatially extensive supply chains in which multi-modal logistics hubs develop inland and away from the port-city. Although the port regionalisation phase is largely driven by both push and pull factors, a scope of action remains for public policy to shape its spatial contours.

In this paper we have argued for the inclusion of a relational perspective of port regionalisation that shows how agency constructs places in a (global) system of flows that is not a functionalist logic of the 'global' imposing development on the 'local' places (i.e., ECT's extended gate). Rather, port regionalisation as a pure spatial outcome is the result of a delicate relational process in which interests from various scales converge in the formation of policy agendas and strategic decision-making and materialise through the process of strategic coupling. This is why the issue of the 'direction' of the regionalisation phase is more delicate and subtle than the functionalist logic of the 'outside-in' or 'inside-out' dichotomy. Indeed, both forces are at work in the rise of Venlo as an inland logistics hub, with many other actors and interests involved than the private terminal operating company ECT. A relational approach thus reveals that the proliferation of Venlo as an inland logistics hub is more nuanced than the accommodation of ECTs extended gateway business model. Only by looking at how agents employ assets (land and location) and confer meaning to a place through discursive practices (Greenport) across scales (national planning support) and within networks (ECT's extended gateway but also the promotional alignment with the PA of Rotterdam, the agri-business sector and the client portfolio of globally specialised real estate-firms) can we fully appreciate how Venlo has become constituted as a logistics hub and, eventually locking-in a development path.

In general, we think that port regionalisation as a process and outcome is also of interest to planners and urban geographers. Planners, urban geographers and historians remain absent in the discussion of this extension of Bird's Anyport model because their studies largely focus on the urban waterfront redevelopment stage. Port regionalisation shows that the development of inland logistics hubs in semi-urban and semi-peripheral locations are as much a part of the wider structural changes as the actual retreat of transport activity from waterfront locations in urban cores. The case study of Venlo shows how 'global-local spaces' emerge 'beyond the waterfront' and materialise in specifically built forms, governance arrangements and economic development trajectories. 


\section{Literature:}

BATHELT H, AND J. GLUECKLER (2003), Towards a relational economic geography. Journal of Economic Geography 3, pp. 117-144.

BIRD, J. (1963), The major seaports of the United Kingdom. London: Hutchinson of London.

BIRD, J. (1973), Of central places, cities and seaports. Geography 58, pp. 105-118.

BRINK, M. VAN DEN (2009), Rijkswaterstaat on the horns of a dilemma, PhD-thesis, Radboud University Nijmegen.

BuitelaAR, E., LAGENDiJK, A. AND W. JACOBS (2007), A theory of institutional change: illustrated by Dutch city-provinces and Dutch land policy. Environment and Planning A 39(4), pp. 891-908.

Coe, N.M., Hess M., Yeung, H.W., Dicken, P. And J. Henderson (2004), Globalizing regional development: a global networks perspective. Transactions of the Institute of British Geographers 29, pp. 468-484.

Coe, N.M., DiCKEn, P. ANd M. Hess (2008), Global production networks: realizing the potential. Journal of Economic Geography 8, pp. 271-295.

Cox, K.R. (1998). Spaces of Dependence, Spaces of Engagement and the Politics of Scale. Political Geography 17, pp. 1-23.

Dicken, P., Kelly, P.F., Olds, K. AND H. W-C. Yeung, H. W-C. (2001), Chains and networks, territories and scales: towards a relational framework for analysing the global economy. Global Networks 1, pp. 1470-2266.

FALUdI, A. (1996), Framing with Images, Environment and Planning B: Planning and Design 23(1), pp. 93-108.

FAure, A. (2010), Territoires/Territorialisation. In L. BouSSAGUET., S. JACQUOT, P. RAVINET, eds., Dictionnaire des politiques publiques, pp. 591-599. Paris: Presses de Sciences-Po.

HAJER, M.A. (1995), The politics of environmental discourse : ecological modernization and the policy process. Oxford: Oxford University Press.

Hall, P.V. AND M. Hesse (2013), eds., Cities, Regions and Flows. London: Routledge.

HAYUTH, Y. (1982), The port-urban interface: an area in transition. Area, pp. 219-224.

Hein, C. (2011), ed., Port Cities. Dynamic Landscapes and Global Networks, London: Routledge, $285 \mathrm{p}$.

Hesse, M. (2004), Land for logistics: locational dynamics, real estate markets and political regulation of regional distribution complexes. Tijdschrift voor economische en sociale geografie 95 (2), pp. 162-173.

HESSE, M. (2013), Cities and flows: re-asserting a relationship as fundamental as it is delicate. Journal of Transport Geography 29, pp. 33-42.

Heuvel, F.P. VAN DEN, DE LANGEN, P.W., DonselaAR, K.H. AND J.C. VAN, Fransoo (2013), Spatial concentration and location dynamics in logistics: the case of a Dutch province. Journal of Transport Geography 28, pp. 39-48. 
HoRST, M.R.. VAN DER AND P. W. DE LANGEN (2008), Coordination in hinterland transport chains: a major challenge for the seaport community. Maritime Economics \& Logistics, 10(1), pp. 108-129.

HoYLE, B.S. (1989), The port-city interface: trends, problems and examples. Geoforum 20, pp. 429-435.

JACOBS, W. (2007), Political economy of port competition. Institutional analysis from Rotterdam, Southern California and Dubai. Nijmegen: Academic Press Europe.

JACobS, W. And A. LAGENDIJK (2014), Strategic Coupling as Capacity. How seaports connect to globalized flows of containerized traffic, Global Networks, 14, 1, pp. 44-62.

JACOBS, W. AND T.E. NotTEBоom (2011), An evolutionary perspective on regional port systems: the role of windows of opportunity in shaping seaport competition. Environment and Planning A 43, pp. 1674-1692.

Logan, J. and H. Molotch (1987), Urban Fortunes. The Political Economy of Place. Berkeley: University of California Press, 413 p.

NeEdham, B. (1997), Land policy in the Netherlands. Tijdschrift voor de Economische and Sociale Geografie, 88: 291-296.

NoRCLIFFe, G, BASSETT, K. AND T. HoARE (1996), The emergence of postmodernism on the urban waterfront. Journal of Transport Geography 4(2), pp. 123-134.

Notтевоом, T.E. (2009), Complementarity and substitutability among adjacent gateway ports. Environment and Planning A 41(3), pp 743-762.

NotTeboom, T.E. AND J.-P. RodRigUe (2005), Port regionalization: towards a new phase in port development. Maritime Policy and Management 32 (3), pp. 297-313.

MACLEOD, G. (2011), Urban politics reconsidered. growth machine to post-democratic city? Urban Studies 48 (12), pp. 2629-2660.

Monios, J. AND G. WiLmsmeier (2012), Giving a direction to port regionalisation. Transportation Research Part A 46, pp. 1551-1561

Raimbault, N. (2013a), Les firmes de l'immobilier logistique - 1, portrait d'entreprise. Flux, 92, pp. 62-74.

RAImbault, N. (2013b), Les firmes de l'immobilier logistique - 2. Prologis : "Local partner to global trade". Une firme intégrée et globale dans l'immobilier logistique, portrait d'entreprise. Flux, 93/94, pp. 91-103.

REIN, M. AND D. SchöN (1986), Frame-reflective policy discourse. Beleidsanalyse 15 (4), pp. 4-18.

Rodrigue, J.-P. AND T.E. NotTEBoom (2009), The terminalization of supply chains: reassessing the role of terminals in port/hinterland logistical relationships. Maritime Policy \& Management: The flagship journal of international shipping and port research, 36:2, pp. 165-183.

Rodrigue, J.-P., Debrie, J., Frémont, A. ANd E. Gouvernal (2010), Functions and Actors of Inland ports: European and North American Dynamics. Journal of transport geography, $18: 3$, pp. 519-529.

STONE, C. N. (1989), Regime Politics: Governing Atlanta, 1946-1988. Lawrence: University Press of Kansas. 
STORPER, M. (1997), The Regional World. Territorial Development in a Global Economy. New York: Guilford Press.

SuNLEY, P. (2008), Relational Economic Geography: a partial understanding or a new paradigm? Economic Geography 84 (1), pp. 1-25.

WIEGMANS, B. AND E. LouW, (2011), Changing port city relationships at Amsterdam: a new phase in the interface? Journal of Transport Geography 19, pp. 575-83.

Wilmsmeier, G., Monios, J. AND B. LAMBert (2011), The directional development of intermodal freight corridors in relation to inland terminals. Journal of Transport Geography 19, pp. 1379-1386.

YEUNG, H. W-C (2005), Rethinking relational economic geography. Transactions of the Institute of British Geographers New Series 30, pp. 37-51.

YEUNG, H. W-C (2009), Regional development and the competitive dynamics of global production networks: An East Asian perspective. Regional Studies 43 (3), pp. 325-351. 